DOI $10.31489 / 2020 \mathrm{M} 3 / 120-129$

MSC 65M06, 65N06, 35M10, 35R30

\author{
Maksat Ashyraliyev $^{1}$, Maral A. Ashyralyyeva ${ }^{2}$, Allaberen Ashyralyev ${ }^{3,4,5}$ \\ ${ }^{1}$ Department of Software Engineering, Bahcesehir University, Istanbul, Turkey \\ ${ }^{2}$ Department of Applied Mathematics and Informatics, Turkmen State University, Ashgabat, Turkmenistan \\ ${ }^{3}$ Department of Mathematics, Near East University,Nicosia, TRNC, Mersin 10, Turkey \\ ${ }^{4}$ Peoples' Friendship University of Russia (RUDN University), 6 Miklukho-Maklaya St, \\ Moscow 117198 Russian Federation \\ ${ }^{5}$ Institute of Mathematics and Mathematical Modeling, 050010, Almaty, Kazakhstan \\ (E-mail: ${ }^{1}$ maksat.ashyralyyev@eng.bau.edu.tr, ${ }^{2}$ ashyrmaral2010@mail.ru, ${ }^{3}$ allaberen.ashyralyev@neu.edu.tr)
}

\title{
A note on the hyperbolic-parabolic identification problem with involution and Dirichlet boundary condition
}

In the present paper, a source identification problem for hyperbolic-parabolic equation with involution and Dirichlet condition is studied. The stability estimates for the solution of the source identification hyperbolicparabolic problem are established. The first order of accuracy stable difference scheme is constructed for the approximate solution of the problem under consideration. Numerical results are given for a simple test problem.

Keywords: source identification problem, hyperbolic-parabolic differential equation, difference scheme, stability.

\section{Introduction}

Partial differential equations with unknown source terms are used to model the behaviour of reallife systems in many different areas of science and technology. They have been studied extensively by many researchers (see, e.g., [1]-[13] and the references therein). Numerous source identification problems for hyperbolic-parabolic equations and the corresponding difference schemes for their approximate solutions were previously studied by the authors (see [14]-[18]. Partial differential equations with the involution have been recently investigated in [19]-[22] However, source identification problems for hyperbolic-parabolic equation with involution have not been investigated.

The present paper is devoted to the study of source identification problems for hyperbolic-parabolic differential and difference equations with involution. The stability of these source identification problems is established. Numerical results are presented.

\section{Stability of differential equation}

We consider the space-dependent source identification problem

$$
\left\{\begin{array}{c}
u_{t t}(t, x)-\left(a(x) u_{x}(t, x)\right)_{x}-\beta\left(a(-x) u_{x}(t,-x)\right)_{x}+\delta u(t, x) \\
\quad=p(x)+f(t, x),-\ell<x<\ell, 0<t<1, \\
u_{t}(t, x)-\left(a(x) u_{x}(t, x)\right)_{x}-\beta\left(a(-x) u_{x}(t,-x)\right)_{x}+\delta u(t, x) \\
\quad=p(x)+g(t, x),-\ell<x<\ell,-1<t<0 \\
u\left(0^{+}, x\right)=u\left(0^{-}, x\right), u_{t}\left(0^{+}, x\right)=u_{t}\left(0^{-}, x\right),-\ell \leq x \leq \ell, \\
u(t,-\ell)=u(t, \ell)=0,-1 \leq t \leq 1, \\
u(-1, x)=\varphi(x), u(1, x)=\psi(x),-\ell \leq x \leq \ell
\end{array}\right.
$$

for one-dimensional hyperbolic-parabolic differential equation with involution. Throughout this paper, we will assume that $\bar{a} \geq a(x)=a(-x) \geq \underline{a}>0, x \in(-\ell, \ell)$ and $\underline{a}-\bar{a}|\beta| \geq 0$. Under compatibility 
conditions problem (1) has a unique smooth solution $(u(t, x), p(x))$ for the given smooth functions $a(x), \varphi(x), \psi(x), x \in[-\ell, \ell], f(t, x),(t, x) \in(0,1) \times(-\ell, \ell), g(t, x),(t, x) \in(-1,0) \times(-\ell, \ell)$ and constant $\delta>0$.

Let the Sobolev space $W_{2}^{2}[-\ell, \ell]$ be defined as the set of all functions $v(x)$ defined on $[-\ell, \ell]$ such that $v(x)$ and the second order derivative function $v^{\prime \prime}(x)$ are both locally integrable in $L_{2}[-\ell, \ell]$, equipped with the norm

$$
\|v(x)\|_{W_{2}^{2}[-\ell, \ell]}=\left(\int_{-\ell}^{\ell}|v(x)|^{2} d x\right)^{1 / 2}+\left(\int_{-\ell}^{\ell}\left|v^{\prime \prime}(x)\right|^{2} d x\right)^{1 / 2} .
$$

Theorem 1. Suppose that $\varphi, \psi \in W_{2}^{2}[-\ell, \ell]$. Let function $f(t, x)$ be continuously differentiable in $t$ on $[0,1] \times[-\ell, \ell]$ and function $g(t, x)$ be continuously differentiable in $t$ on $[-1,0] \times[-\ell, \ell]$. Then the solution of the identification problem (1) satisfies the stability estimates

$$
\begin{gathered}
\|u\|_{C\left([-1,1], L_{2}[-\ell, \ell]\right)}+\left\|\left(A^{x}\right)^{-1} p\right\|_{L_{2}[-\ell, \ell]} \\
\leq M_{1}(\delta)\left[\|\varphi\|_{L_{2}[-\ell, \ell]}+\|\psi\|_{L_{2}[-\ell, \ell]}+\|f\|_{C\left([0,1], L_{2}[-\ell, \ell]\right)}+\|g\|_{C\left([-1,0], L_{2}[-\ell, \ell]\right)}\right], \\
\|u\|_{C^{(2)}\left([0,1], L_{2}[-\ell, \ell]\right)}+\|u\|_{C^{(1)}\left([-1,0], L_{2}[-\ell, \ell]\right)}+\|u\|_{C\left([-1,1], W_{2}^{2}[-\ell, \ell]\right)}+\|p\|_{L_{2}[-\ell, \ell]} \\
\leq M_{2}(\delta)\left[\|\varphi\|_{W_{2}^{2}[-\ell, \ell]}+\|\psi\|_{W_{2}^{2}[-\ell, \ell]}+\|f\|_{C^{(1)}\left([0,1], L_{2}[-\ell, \ell]\right)}+\|g\|_{C^{(1)}\left([-1,0], L_{2}[-\ell, \ell]\right)}\right],
\end{gathered}
$$

where $M_{1}(\delta)$ and $M_{2}(\delta)$ do not depend on $\varphi(x), \psi(x), f(t, x)$ and $g(t, x)$.

Proof. Problem (1) can be written in the following abstract form

$$
\left\{\begin{array}{l}
u^{\prime \prime}(t)+A u(t)=p+f(t), 0<t<1 \\
u^{\prime}(t)+A u(t)=p+g(t),-1<t<0 \\
u\left(0^{+}\right)=u\left(0^{-}\right), u^{\prime}\left(0^{+}\right)=u^{\prime}\left(0^{-}\right) \\
u(-1)=\varphi, u(1)=\psi
\end{array}\right.
$$

in a Hilbert space $L_{2}[-\ell, \ell]$ with self-adjoint positive definite operator $A=A^{x}$ defined by the formula

$$
A^{x} u(x)=-\left(a(x) u_{x}(x)\right)_{x}-\beta\left(a(-x) u_{x}(-x)\right)_{x}+\delta u(x)
$$

with the domain $D\left(A^{x}\right)=\left\{u \in W_{2}^{2}[-\ell, \ell] \mid u(-\ell)=u(\ell)=0\right\}$. Here, $f(t)=f(t, x)$ and $g(t)=g(t, x)$ are given abstract functions, $u(t)=u(t, x)$ is unknown function and $p=p(x)$ is the unknown element of $L_{2}[-\ell, \ell]$. Therefore, the proof of Theorem 1 is based on the self-adjointness and positive definiteness of the space operator $A^{x}$ (see [19]).

\section{Stability of difference scheme}

Now, we study the stable difference scheme for the approximate solution of identification problem (1). The discretization of source identification problem (1) is carried out in two steps.

In the first step, the spatial discretization is carried out. We define the grid space

$$
[-\ell, \ell]_{h}=\left\{x=x_{n} \mid x_{n}=n h,-M \leq n \leq M, M h=\ell\right\} .
$$

We introduce the Hilbert space $L_{2 h}=L_{2}\left([-\ell, \ell]_{h}\right)$ of the grid functions $\varphi^{h}(x)=\left\{\varphi^{n}\right\}_{-M}^{M}$ defined on $[-\ell, \ell]_{h}$, equipped with the norm

$$
\left\|\varphi^{h}\right\|_{L_{2 h}}=\left(\sum_{x \in[-\ell, \ell]_{h}}\left|\varphi^{h}(x)\right|^{2} h\right)^{1 / 2}
$$


To the differential operator $A^{x}$ defined by the formula (2), we assign the difference operator $A_{h}^{x}$ by the formula

$$
A_{h}^{x} \varphi^{h}(x)=\left\{-\left(a(x) \varphi_{\bar{x}}^{n}\right)_{x}-\beta\left(a(-x) \varphi_{\bar{x}}^{-n}\right)_{x}+\delta \varphi^{n}\right\}_{-M+1}^{M-1},
$$

acting in the space of grid functions $\varphi^{h}(x)=\left\{\varphi^{n}\right\}_{-M}^{M}$ and satisfying the conditions $\varphi_{-M}=\varphi_{M}=0$. Here

$$
\varphi_{\bar{x}}^{n}=\frac{\varphi^{n}-\varphi^{n-1}}{h},-M+1 \leq n \leq M, \quad \varphi_{x}^{n}=\frac{\varphi^{n+1}-\varphi^{n}}{h},-M \leq n \leq M-1 .
$$

It is well-known that $A_{h}^{x}$, defined by (3), is a self-adjoint positive definite operator in $L_{2 h}$. With the help of $A_{h}^{x}$, the first discretization step results in the following identification problem

$$
\left\{\begin{array}{l}
u_{t t}^{h}(t, x)+A_{h}^{x} u^{h}(t, x)=p^{h}(x)+f^{h}(t, x), x \in[-\ell, \ell]_{h}, 0<t<1, \\
u_{t}^{h}(t, x)+A_{h}^{x} u^{h}(t, x)=p^{h}(x)+g^{h}(t, x), x \in[-\ell, \ell]_{h},-1<t<0, \\
u^{h}\left(0^{+}, x\right)=u^{h}\left(0^{-}, x\right), u_{t}^{h}\left(0^{+}, x\right)=u_{t}^{h}\left(0^{-}, x\right), x \in[-\ell, \ell]_{h}, \\
u^{h}(-1, x)=\varphi^{h}(x), u^{h}(1, x)=\psi^{h}(x), x \in[-\ell, \ell]_{h} .
\end{array}\right.
$$

In the second step, we replace the identification problem (4) with the following first order of accuracy difference scheme

$$
\left\{\begin{array}{l}
\frac{u_{k+1}^{h}(x)-2 u_{k}^{h}(x)+u_{k-1}^{h}(x)}{\tau^{2}}+A_{h}^{x} u_{k+1}^{h}(x)=p^{h}(x)+f_{k}^{h}(x), 1 \leq k \leq N-1, x \in[-\ell, \ell]_{h}, \\
\frac{u_{k}^{h}(x)-u_{k-1}^{h}(x)}{\tau}+A_{h}^{x} u_{k}^{h}(x)=p^{h}(x)+g_{k}^{h}(x),-N+1 \leq k \leq 0, x \in[-\ell, \ell]_{h}, \\
f_{k}^{h}(x)=f^{h}\left(t_{k}, x\right), 1 \leq k \leq N-1, g_{k}^{h}(x)=g\left(t_{k}, x\right),-N+1 \leq k \leq 0, \quad x \in[-\ell, \ell]_{h}, \\
u_{1}^{h}(x)-u_{0}^{h}(x)=u_{0}^{h}(x)-u_{-1}^{h}(x), u_{-N}^{h}(x)=\varphi^{h}(x), u_{N}^{h}(x)=\psi^{h}(x), x \in[-\ell, \ell]_{h},
\end{array}\right.
$$

where $\tau=1 / N$ and $t_{k}=k \tau,-N \leq k \leq N$.

Theorem 2. Let $\tau$ and $h$ be sufficiently small numbers. For the solution $\left\{\left\{u_{k}^{h}(x)\right\}_{-N}^{N}, p^{h}(x)\right\}$ of problem (5) the following stability estimates

$$
\begin{gathered}
\max _{-N \leq k \leq N}\left\|u_{k}\right\|_{L_{2 h}}+\left\|\left(A_{h}^{x}\right)^{-1} p^{h}\right\|_{L_{2 h}} \\
\leq \tilde{M}_{1}(\delta)\left[\left\|\varphi^{h}\right\|_{L_{2 h}}+\left\|\psi^{h}\right\|_{L_{2 h}}+\max _{-N+1 \leq k \leq 0}\left\|g_{k}^{h}\right\|_{L_{2 h}}+\max _{1 \leq k \leq N-1}\left\|f_{k}^{h}\right\|_{L_{2 h}}\right], \\
\max _{1 \leq k \leq N-1}\left\|\frac{u_{k+1}^{h}-2 u_{k}^{h}+u_{k-1}^{h}}{\tau^{2}}\right\|_{L_{2 h}}^{+} \max _{-N+1 \leq k \leq 0}\left\|\frac{u_{k}^{h}-u_{k-1}^{h}}{\tau}\right\|_{L_{2 h}}+\max _{-N \leq k \leq N}\left\|u_{k}^{h}\right\|_{W_{2 h}^{2}}+\left\|p^{h}\right\|_{L_{2 h}} \\
\leq \tilde{M}_{2}(\delta)\left[\left\|\varphi^{h}\right\|_{W_{2 h}^{2}}+\left\|\psi^{h}\right\|_{W_{2 h}^{2}}+\left\|g_{0}^{h}\right\|_{L_{2 h}}+g_{-N+1 \leq k \leq-1}^{h}\left\|\frac{g_{k-1}^{h}}{\tau}\right\|_{L_{2 h}}\right. \\
\left.+\left\|f_{1}^{h}\right\|_{L_{2 h}}+\max _{2 \leq k \leq N-1}\left\|\frac{f_{k}^{h}-f_{k-1}^{h}}{\tau}\right\|_{L_{2 h}}\right]
\end{gathered}
$$

hold, where $\tilde{M}_{1}(\delta)$ and $\tilde{M}_{2}(\delta)$ do not depend on $\tau, h, f_{k}^{h}, 1 \leq k \leq N-1, g_{k}^{h},-N+1 \leq k \leq 0, \varphi^{h}(x)$ and $\psi^{h}(x)$. 
Proof. Difference scheme (5) can be written in the following abstract form

$$
\left\{\begin{array}{l}
\frac{u_{k+1}^{h}-2 u_{k}^{h}+u_{k-1}^{h}}{\tau^{2}}+A_{h} u_{k+1}^{h}=p^{h}+f_{k}^{h}, 1 \leq k \leq N-1, \\
\frac{u_{k}^{h}-u_{k-1}^{h}}{\tau}+A_{h} u_{k}^{h}=p^{h}+g_{k}^{h},-N+1 \leq k \leq 0 \\
u_{1}^{h}-u_{0}^{h}=u_{0}^{h}-u_{-1}^{h}, u_{-N}^{h}=\varphi^{h}, u_{N}^{h}=\psi^{h}
\end{array}\right.
$$

in a Hilbert space $L_{2 h}$ with operator $A_{h}=A_{h}^{x}$ defined by formula (3). Here, $f_{k}^{h}=f_{k}^{h}(x)$ and $g_{k}^{h}=g_{k}^{h}(x)$ are given abstract functions, $u_{k}^{h}=u_{k}^{h}(x)$ is unknown mesh function and $p^{h}=p^{h}(x)$ is the unknown mesh element of $L_{2 h}$. Therefore, the proof of Theorem 2 is based on the self-adjointness and positive definiteness of the space operator $A_{h}$ in $L_{2 h}$ [23].

\section{Numerical experiments}

When the analytical methods do not work properly, the numerical methods for obtaining the approximate solutions of partial differential equations play an important role in applied mathematics. In this section, we will use the first order of accuracy difference scheme to approximate the solution of a simple test problem. We will apply a procedure of modified Gauss elimination method to solve the problem. Finally, the error analysis of first order of accuracy difference scheme will be given.

We consider the identification problem with the Dirichlet condition

$$
\left\{\begin{array}{l}
u_{t t}(t, x)-u_{x x}(t, x)-\frac{1}{2}\left(u_{x}(t,-x)\right)_{x}+u(t, x)=p(x)+f(t, x), x \in(-\pi, \pi), t \in(0,1), \\
u_{t}(t, x)-u_{x x}(t, x)-\frac{1}{2}\left(u_{x}(t,-x)\right)_{x}+u(t, x)=p(x)+g(t, x), x \in(-\pi, \pi), t \in(-1,0), \\
u(-1, x)=\varphi(x), u(1, x)=\psi(x), x \in[-\pi, \pi], \\
u(t,-\pi)=u(t, \pi)=0, t \in[-1,1]
\end{array}\right.
$$

for one-dimensional hyperbolic-parabolic equation with involution, where

$$
\begin{aligned}
& f(t, x)=\left(\frac{1}{2} \cos t-1\right) \sin x, x \in(-\pi, \pi), t \in(0,1), \\
& g(t, x)=\left(\frac{3}{2} \cos t-\sin t-1\right) \sin x, x \in(-\pi, \pi), t \in(-1,0), \\
& \varphi(x)=\cos 1 \sin x, \psi(x)=\cos 1 \sin x, x \in[-\pi, \pi] .
\end{aligned}
$$

The exact solution of problem (6) is the pair of functions

$$
(u(t, x), p(x))=(\cos t \sin x, \sin x),-\pi \leq x \leq \pi,-1 \leq t \leq 1 .
$$

We define the set $[-1,1]_{\tau} \times[-\pi, \pi]_{h}$ of all grid points as following:

$$
[-1,1]_{\tau} \times[-\pi, \pi]_{h}=\left\{\left(t_{k}, x_{n}\right) \mid t_{k}=k \tau,-N \leq k \leq N, N \tau=1, x_{n}=n h,-M \leq n \leq M, M h=\pi\right\} .
$$

For the numerical solution of source identification problem (6), we construct the first order of accuracy difference scheme in $t$ 


$$
\left\{\begin{array}{l}
\frac{u_{n}^{k+1}-2 u_{n}^{k}+u_{n}^{k-1}}{\tau^{2}}-\frac{u_{n+1}^{k+1}-2 u_{n}^{k+1}+u_{n-1}^{k+1}}{h^{2}}-\frac{u_{-n+1}^{k+1}-2 u_{-n}^{k+1}+u_{-n-1}^{k+1}}{2 h^{2}}+u_{n}^{k+1} \\
\quad=p_{n}+f\left(t_{k}, x_{n}\right), 1 \leq k \leq N-1,-M+1 \leq n \leq M-1, \\
\frac{u_{n}^{k}-u_{n}^{k-1}}{\tau}-\frac{u_{n+1}^{k}-2 u_{n}^{k}+u_{n-1}^{k}-\frac{u_{-n+1}^{k}-2 u_{-n}^{k}+u_{-n-1}^{k}}{h^{2}}+u_{n}^{k}}{2 h^{2}} \\
\quad=p_{n}+g\left(t_{k}, x_{n}\right),-N+1 \leq k \leq 0,-M+1 \leq n \leq M-1, \\
u_{n}^{1}-u_{n}^{0}=u_{n}^{0}-u_{n}^{-1}, u_{n}^{-N}=\varphi\left(x_{n}\right), u_{n}^{N}=\psi\left(x_{n}\right),-M \leq n \leq M, \\
u_{-M}^{k}=u_{M}^{k}=0,-N \leq k \leq N,
\end{array}\right.
$$

where $u_{n}^{k}$ and $p_{n}$ denote the numerical approximations of $u(t, x)$ at $(t, x)=\left(t_{k}, x_{n}\right)$ and $p(x)$ at $x=x_{n}$, respectively. The solution of difference scheme (7) can be found in the form

$$
\begin{aligned}
u_{n}^{k}= & v_{n}^{k}-v_{n}^{N}+\psi\left(x_{n}\right),-M \leq n \leq M,-N \leq k \leq N, \\
p_{n}= & \psi\left(x_{n}\right)-\frac{\psi\left(x_{n+1}\right)-2 \psi\left(x_{n}\right)+\psi\left(x_{n-1}\right)}{h^{2}}-\frac{\psi\left(x_{-n+1}\right)-2 \psi\left(x_{-n}\right)+\psi\left(x_{-n-1}\right)}{2 h^{2}} \\
& +\frac{v_{n+1}^{N}-2 v_{n}^{N}+v_{n-1}^{N}}{h^{2}}+\frac{v_{-n+1}^{N}-2 v_{-n}^{N}+v_{-n-1}^{N}}{2 h^{2}}-v_{n}^{N},-M+1 \leq n \leq M-1,
\end{aligned}
$$

where $\left\{\left\{v_{n}^{k}\right\}_{k=-N}^{N}\right\}_{n=-M}^{M}$ is the solution of the following nonlocal boundary value problem

$$
\left\{\begin{array}{l}
\frac{v_{n}^{k+1}-2 v_{n}^{k}+v_{n}^{k-1}}{\tau^{2}}-\frac{v_{n+1}^{k+1}-2 v_{n}^{k+1}+v_{n-1}^{k+1}}{h^{2}}-\frac{v_{-n+1}^{k+1}-2 v_{-n}^{k+1}+v_{-n-1}^{k+1}}{2 h^{2}}+v_{n}^{k+1} \\
\quad=f\left(t_{k}, x_{n}\right), 1 \leq k \leq N-1,-M+1 \leq n \leq M-1, \\
\frac{v_{n}^{k}-v_{n}^{k-1}}{\tau}-\frac{v_{n+1}^{k}-2 v_{n}^{k}+v_{n-1}^{k}-\frac{v_{-n+1}^{k}-2 v_{-n}^{k}+v_{-n-1}^{k}}{h^{2}}+v_{n}^{k}}{2 h^{2}} \\
\quad=g\left(t_{k}, x_{n}\right),-N+1 \leq k \leq 0,-M+1 \leq n \leq M-1, \\
v_{n}^{1}-v_{n}^{0}=v_{n}^{0}-v_{n}^{-1}, v_{n}^{N}-v_{n}^{-N}=\psi\left(x_{n}\right)-\varphi\left(x_{n}\right),-M \leq n \leq M, \\
v_{-M}^{k}=v_{M}^{k}=0,-N \leq k \leq N .
\end{array}\right.
$$

To obtain the solution of difference scheme (8), we first rewrite it in the matrix form

$$
\left\{\begin{array}{l}
A V_{n+1}+B V_{n}+A V_{n-1}+C V_{-n+1}+D V_{-n}+C V_{-n-1}=F_{n},-M+1 \leq n \leq M-1, \\
V_{-M}=V_{M}=\tilde{0},
\end{array}\right.
$$

where $\tilde{0}$ is $(2 N+1) \times 1$ zero vector and

$$
A=\left[\begin{array}{cccccccc}
0 & 0 & \cdots & 0 & 0 & 0 & \cdots & 0 \\
0 & a & \cdots & 0 & 0 & 0 & \cdots & 0 \\
\vdots & \vdots & \ddots & \vdots & \vdots & \vdots & & \vdots \\
0 & 0 & \cdots & a & 0 & 0 & \cdots & 0 \\
0 & 0 & \cdots & 0 & 0 & 0 & \cdots & 0 \\
0 & 0 & \cdots & 0 & 0 & b & \cdots & 0 \\
\vdots & \vdots & & \vdots & \vdots & \vdots & \ddots & \vdots \\
0 & 0 & \cdots & 0 & 0 & 0 & \cdots & b
\end{array}\right]_{(2 N+1) \times(2 N+1)} \quad F_{n}=\left[\begin{array}{c}
\psi\left(x_{n}\right)-\varphi\left(x_{n}\right) \\
\tau g\left(t_{-N+1}, x_{n}\right) \\
\vdots \\
\tau g\left(t_{0}, x_{n}\right) \\
0 \\
\tau^{2} f\left(t_{1}, x_{n}\right) \\
\vdots \\
\tau^{2} f\left(t_{N-1}, x_{n}\right)
\end{array}\right]_{(2 N+1) \times 1}
$$




$$
C=\left[\begin{array}{cccccccc}
0 & 0 & \cdots & 0 & 0 & 0 & \cdots & 0 \\
0 & q & \cdots & 0 & 0 & 0 & \cdots & 0 \\
\vdots & \vdots & \ddots & \vdots & \vdots & \vdots & & \vdots \\
0 & 0 & \cdots & q & 0 & 0 & \cdots & 0 \\
0 & 0 & \cdots & 0 & 0 & 0 & \cdots & 0 \\
0 & 0 & \cdots & 0 & 0 & r & \cdots & 0 \\
\vdots & \vdots & & \vdots & \vdots & \vdots & \ddots & \vdots \\
0 & 0 & \cdots & 0 & 0 & 0 & \cdots & r
\end{array}\right]_{(2 N+1) \times(2 N+1)} \quad V_{n}=\left[\begin{array}{c}
v_{n}^{-N} \\
v_{n}^{-N+1} \\
\vdots \\
v_{n}^{0} \\
v_{n}^{1} \\
v_{n}^{2} \\
\vdots \\
v_{n}^{N}
\end{array}\right]_{(2 N+1) \times 1}
$$

$$
\left.\begin{array}{rl}
B=\left[\begin{array}{cccccccccccc}
-1 & 0 & \cdots & 0 & 0 & 0 & 0 & \cdots & 0 & 0 & 1 \\
-1 & c & \cdots & 0 & 0 & 0 & 0 & \cdots & 0 & 0 & 0 \\
\vdots & \vdots & \ddots & \ddots & \vdots & \vdots & \vdots & & \vdots & \vdots & \vdots \\
0 & 0 & \cdots & -1 & c & 0 & 0 & \cdots & 0 & 0 & 0 \\
0 & 0 & \cdots & 1 & -2 & 1 & 0 & \cdots & 0 & 0 & 0 \\
& 0 & 0 & \cdots & 0 & 1 & -2 & d & \cdots & 0 & 0 & 0 \\
& \vdots & \vdots & & \vdots & \vdots & \vdots & \vdots & \ddots & \ddots & \ddots & \vdots \\
& 0 & 0 & \cdots & 0 & 0 & 0 & 0 & \cdots & 1 & -2 & d
\end{array}\right]_{(2 N+1) \times(2 N+1)} \\
D=\left[\begin{array}{cccccccc}
0 & 0 & \cdots & 0 & 0 & 0 & \cdots & 0 \\
0 & s & \cdots & 0 & 0 & 0 & \cdots & 0 \\
\vdots & \vdots & \ddots & \vdots & \vdots & \vdots & & \vdots \\
0 & 0 & \cdots & s & 0 & 0 & \cdots & 0 \\
0 & 0 & \cdots & 0 & 0 & 0 & \cdots & 0 \\
0 & 0 & \cdots & 0 & 0 & \sigma & \cdots & 0 \\
\vdots & \vdots & & \vdots & \vdots & \vdots & \ddots & \vdots \\
0 & 0 & \cdots & 0 & 0 & 0 & \cdots & \sigma
\end{array}\right]_{(2 N+1) \times(2 N+1)} \\
v_{-n}^{-N} \\
v_{-n}^{-N+1} \\
\vdots \\
v_{-n}^{0} \\
v_{-n}^{1} \\
v_{-n}^{2} \\
\vdots \\
v_{-n}^{N}
\end{array}\right]_{(2 N+1) \times 1}
$$

with $a=-\frac{\tau}{h^{2}}, b=-\frac{\tau^{2}}{h^{2}}, c=1+\frac{2 \tau}{h^{2}}+\tau, d=1+\frac{2 \tau^{2}}{h^{2}}+\tau^{2}, q=-\frac{\tau}{2 h^{2}}, r=-\frac{\tau^{2}}{2 h^{2}}, s=\frac{\tau}{h^{2}}, \sigma=\frac{\tau^{2}}{h^{2}}$. Next, we rewrite the system (9) as following

$$
\left\{\begin{array}{l}
\tilde{A} Z_{n+1}+\tilde{B} Z_{n}+\tilde{A} Z_{n-1}=\phi_{n}, 1 \leq n \leq M-1, \\
\tilde{C} Z_{1}+\tilde{B} Z_{0}=\phi_{0} \\
Z_{M}=\tilde{0}
\end{array}\right.
$$

where $\tilde{A}=\left[\begin{array}{ll}A & C \\ C & A\end{array}\right], \tilde{B}=\left[\begin{array}{cc}B & D \\ D & B\end{array}\right]$ and $\tilde{C}=\tilde{A}+\left[\begin{array}{cc}C & A \\ A & C\end{array}\right]$ are $(4 N+2) \times(4 N+2)$ matrices, $Z_{n}=\left[\begin{array}{c}V_{n} \\ V_{-n}\end{array}\right]$ and $\phi_{n}=\left[\begin{array}{c}F_{n} \\ F_{-n}\end{array}\right]$ are $(4 N+1) \times 1$ column vectors. Now, the matrix equation (10) can be solved by using the modified Gauss elimination method [24]. We seek a solution of the matrix equation (10) in the following form:

$$
\left\{\begin{array}{l}
Z_{n}=\alpha_{n+1} Z_{n+1}+\beta_{n+1}, n=M-1, \ldots, 2,1, \\
Z_{M}=\tilde{0},
\end{array}\right.
$$


where $\alpha_{n}$ are $(4 N+2) \times(4 N+2)$ square matrices and $\beta_{n}$ are $(4 N+2) \times 1$ column vectors, calculated by

$$
\left\{\begin{array}{l}
\alpha_{n+1}=-\left(\tilde{B}+\tilde{A} \alpha_{n}\right)^{-1} \tilde{A} \\
\beta_{n+1}=\left(\tilde{B}+\tilde{A} \alpha_{n}\right)^{-1}\left(\phi_{n}-\tilde{A} \beta_{n}\right)
\end{array}\right.
$$

for $n=1,2, \ldots, M-1$. Here, $\alpha_{1}=-\tilde{B}^{-1} \tilde{C}$ and $\beta_{1}=\tilde{B}^{-1} \phi_{0}$.

The numerical solutions of the first order of accuracy difference scheme (7) are computed for different values of $M$ and $N$ by using the algorithm described above. We measure the error between the exact solution and numerical solution by

$$
\left\|E_{u}\right\|_{\infty}=\max _{\substack{-N+1 \leq k \leq N-1 \\-M+1 \leq n \leq M-1}}\left|u\left(t_{k}, x_{n}\right)-u_{n}^{k}\right|, \quad\left\|E_{p}\right\|_{\infty}=\max _{-M+1 \leq n \leq M-1}\left|p\left(x_{n}\right)-p_{n}\right|,
$$

where $u\left(t_{k}, x_{n}\right)$ is the exact value of $u(t, x)$ at $\left(t_{k}, x_{n}\right)$ and $p\left(x_{n}\right)$ is the exact value of source $p(x)$ at $x=x_{n} ; u_{n}^{k}$ and $p_{n}$ represent the corresponding numerical solutions. Table 1 shows the errors between the exact solution of the problem (6) and the numerical solutions computed by using the first order of accuracy scheme. We observe that the scheme has the first order convergence as it is expected to be.

Таблица 1: The errors between the exact solution of the problem (6) and the numerical solutions computed by using the first order of accuracy difference scheme (7) for different values of $h=\frac{\pi}{M}$ and $\tau=\frac{1}{N}$.

\begin{tabular}{|l|c|c|c|c|}
\hline & $\left\|E_{p}\right\|_{\infty}$ & Order & $\left\|E_{u}\right\|_{\infty}$ & Order \\
\hline$N=M=20$ & $4.9976 \times 10^{-2}$ & - & $3.6439 \times 10^{-2}$ & - \\
\hline$N=M=40$ & $2.5072 \times 10^{-2}$ & 0.9951 & $1.8518 \times 10^{-2}$ & 0.9765 \\
\hline$N=M=80$ & $1.2558 \times 10^{-2}$ & 0.9975 & $9.3355 \times 10^{-3}$ & 0.9881 \\
\hline$N=M=160$ & $6.2845 \times 10^{-3}$ & 0.9987 & $4.6871 \times 10^{-3}$ & 0.9940 \\
\hline$N=M=320$ & $3.1436 \times 10^{-3}$ & 0.9994 & $2.3484 \times 10^{-3}$ & 0.9970 \\
\hline
\end{tabular}

\section{Acknowledgement}

The publication has been prepared with the support of the "RUDN University Program 5-100".

\section{References}

1 Dehghan M. Determination of a control parameter in the two-dimensional diffusion equation / M. Dehghan // Appl. Numer. Math. - 2001. - 37. - P. 489-502.

2 Kimura T. A parabolic inverse problem arising in a mathematical model for chromatography / T. Kimura, T. Suzuki // SIAM J. Appl. Math. - 1993. - 53. - P. 1747-1761.

3 Gryazin Y.A. Imaging the diffusion coefficient in a parabolic inverse problem in optical tomography / Y.A. Gryazin, M.V. Klibanov, T.R. Lucas // Inverse Problems. - 1999. - 15. P. 373-397.

4 Eidelman Y.S. Boundary Value Problems for Differential Equations with Parameters / Y.S. Eidelman - PhD thesis, Voronezh State University, 1984.

5 Ashyralyev A. On the problem of determining the parameter of a parabolic equation / A. Ashyralyev // Ukrainian Math. J. - 2011. - 62. - P. 1397-1408. 
6 Orlovskii D.G. Approximation of the Bitsadze-Samarskii inverse problem for an elliptic equation with the Dirichlet conditions / D.G. Orlovskii, S.I. Piskarev // Differential Equations. - 2013. - 49. - 7. - P. 895-907.

7 Ashyralyyev C. Numerical solution to inverse elliptic problem with Neumann type overdetermination and mixed boundary conditions / C. Ashyralyyev, Y. Akkan // Electron. J. Differential Equations. - 2015. - 188. - P. 1-15.

8 Ashyralyev A. On the problem of determining the parameter of an elliptic equation in a Banach space / A. Ashyralyev, C. Ashyralyyev // Nonlinear Anal. Model. Control. - 2014. - 19. P. 350-366.

9 Erdogan A.S. On the second order implicit difference schemes for a right hand side identification problem / A.S. Erdogan, A. Ashyralyev // Appl. Math. Comput. - 2014. - 226. - P. 212-228.

10 Ashyralyev A. On the determination of the right-hand side in a parabolic equation / A. Ashyralyev, A.S. Erdogan, O. Demirdag // Appl. Numer. Math. - 2012. - 62. - P. 1672-1683.

11 Sazaklioglu A.U. Existence and uniqueness results for an inverse problem for semilinear parabolic equations / A.U. Sazaklioglu, A. Ashyralyev, A.S. Erdogan // Filomat. - 2017. - 32. - 4. P. 1057-1064.

12 Ashyralyev A. Investigation of a time-dependent source identification inverse problem with integral overdetermination / A. Ashyralyev, A.U. Sazaklioglu // Numer. Funct. Anal. Optim. - 2017. 38. - 10. - P. 1276-1294.

13 Orazov I. On a class of problems of determining the temperature and density of heat sources given initial and final temperature / I. Orazov, M.A. Sadybekov // Sib. Math. J. - 2012. - 53. - P. 146-151.

14 Ashyralyev A. On source identification problem for a hyperbolic-parabolic equation / A. Ashyralyev, M.A. Ashyralyyeva // Contemporary Analysis and Applied Mathematics. - 2015 . - 3. 1. - P. 88-103.

15 Ashyralyyeva M.A. Stable difference scheme for the solution of the source identification problem for hyperbolic-parabolic equations / M.A. Ashyralyyeva, A. Ashyralyyev // AIP Conference Proceedings. - 2015. - 1676. - No. 020024.

16 Ashyralyyeva M. On a second order of accuracy stable difference scheme for the solution of a source identification problem for hyperbolic-parabolic equations / M. Ashyralyyeva, M. Ashyraliyev // AIP Conference Proceedings. - 2016. - 1759. - No. 020023.

17 Ashyralyyeva M. Numerical solutions of source identification problem for hyperbolic-parabolic equations / M. Ashyralyyeva, M. Ashyraliyev // AIP Conference Proceedings. - 2018. - 1997. - No. 020048.

18 Ashyralyyeva M.A. On the numerical solution of identification hyperbolic-parabolic problems with the Neumann boundary condition / M.A. Ashyralyyeva, M. Ashyraliyev // Bulletin of the Karaganda University-Mathematics. - 2018. - 91. - 3. - P. 69-74.

19 Ashyralyev A. Well-posedness of an elliptic equation with involution / A. Ashyralyev, A.M. Sarsenbi // Electron. J. Differential Equations. - 2015. - 284. - P. 1-8.

20 Ashyralyev A. Well-posedness of a parabolic equation with involution / A. Ashyralyev, A. Sarsenbi // Numer. Funct. Anal. Optim. - 2017. - 38. - 10. - P. 1295-1304.

21 Ashyralyev A. Stability of a hyperbolic equation with the involution / A. Ashyralyev, A.M. Sarsenbi // Springer Proc. Math. Stat. - 2016. - 216. - P. 204-212.

22 Ashyralyev A. Stable difference scheme for the solution of an elliptic equation with involution / A. Ashyralyev, B. Karabaeva, A.M. Sarsenbi // AIP Conference Proceedings. - 2016. - 1759. - No. 020111. 
23 Ashyralyev A. New Difference Schemes for Partial Differential Equations, Operator Theory Advances and Applications / A. Ashyralyev, P.E. Sobolevskii. - Birkhäuser Verlag, Basel, Boston, Berlin, 2004. - 444 p.

24 Samarskii A.A. Numerical Methods for Grid Equations: Iterative Methods / A.A. Samarskii, E.S. Nikolaev. - Basel: Birkhauser Verlag, 1989.

М. Ашыралыев, М.А. Ашыралыева, А. Ашыралыев

Шекаралық Дирихле шарттарымен және инволяциясымен сәйкестендірілген гиперболалы-параболалық есебі туралы ескерту

\begin{abstract}
Мақалада инволюциясымен және Дирихле шартымен берілген гиперболалы-параболалық теңдеу үшін дереккөзді сәйкестендіру мәселесі зерттелген. Дереккөзі сәйкестендірілген гиперболалы-параболалық есебі шешімінің орнықтылық бағамы алынған. Қарастырылған есептің жуық шешімі үшін бірінші ретті дәлдікпен орнықты айырымдық схемасы құрастырылды. Қарапайым тестік есептері үшін сандық нәтижелері берілген.
\end{abstract}

Кілт сөздер: дереккөзді сәйкестендіру есебі, гиперболалы-параболалық дифференциалдық теңдеу, айырымдық схема, орнықтылық.

\author{
М. Ашыралыев, М.А. Ашыралыева, А. Ашыралыев \\ Замечание о гиперболо-параболической задаче \\ идентификации с инволюцией и граничным \\ условием Дирихле
}

\begin{abstract}
В статье исследована проблема идентификации источника для гиперболо-параболического уравнения с инволюцией и условием Дирихле. Получены оценки устойчивости решения гиперболо-параболической задачи идентификации источника. Построена устойчивая разностная схема первого порядка точности для приближенного решения рассматриваемой задачи. Приведены численные результаты для простой тестовой задачи.
\end{abstract}

Ключевые слова: задача идентификации источника, гиперболо-параболическое дифференциальное уравнение, разностная схема, устойчивость.

\title{
References
}

1 Dehghan, M. (2001). Determination of a control parameter in the two-dimensional diffusion equation. Appl. Numer. Math., 37, 489-502.

2 Kimura, T. \& Suzuki, T. (1993). A parabolic inverse problem arising in a mathematical model for chromatography. SIAM J. Appl. Math., 53, 1747-1761.

3 Gryazin, Y.A., Klibanov, M.V. \& Lucas, T.R. (1999). Imaging the diffusion coefficient in a parabolic inverse problem in optical tomography. Inverse Problems, 15, 373-397.

4 Eidelman, Y.S. (1984). Boundary Value Problems for Differential Equations with Parameters. $\mathrm{PhD}$ thesis, Voronezh State University [in Russian].

5 Ashyralyev, A. (2011). On the problem of determining the parameter of a parabolic equation. Ukrainian Math. J., 62, 9, 1397-1408.

6 Orlovskii, D.G. \& Piskarev, S.I. (2013). Approximation of the Bitsadze-Samarskii inverse problem for an elliptic equation with the Dirichlet conditions. Differential Equations, 49, 7, 895-907. 
7 Ashyralyyev, C. \& Akkan, Y. (2015). Numerical solution to inverse elliptic problem with Neumann type overdetermination and mixed boundary conditions. Electron. J. Differential Equations, 2015, $188,1-15$.

8 Ashyralyev, A. \& Ashyralyyev, C. (2014). On the problem of determining the parameter of an elliptic equation in a Banach space. Nonlinear Anal. Model. Control, 19, 350-366.

9 Erdogan, A.S. \& Ashyralyev, A. (2014). On the second order implicit difference schemes for a right hand side identification problem. Appl. Math. Comput., 226, 212-228.

10 Ashyralyev, A., Erdogan, A.S. \& Demirdag, O. (2012). On the determination of the right-hand side in a parabolic equation. Appl. Numer. Math., 62, 1672-1683.

11 Sazaklioglu, A.U., Ashyralyev, A. \& Erdogan, A.S. (2017). Existence and uniqueness results for an inverse problem for semilinear parabolic equations. Filomat, 32, 4, 1057-1064.

12 Ashyralyev, A. \& Sazaklioglu, A.U. (2017). Investigation of a time-dependent source identification inverse problem with integral overdetermination. Numer. Funct. Anal. Optim., 38, 10, 1276-1294.

13 Orazov, I. \& Sadybekov, M.A. (2012). On a class of problems of determining the temperature and density of heat sources given initial and final temperature. Sib. Math. J., 53, 146-151.

14 Ashyralyev, A. \& Ashyralyyeva, M.A. (2015). On source identification problem for a hyperbolicparabolic equation. Contemporary Analysis and Applied Mathematics, 3, 1, 88-103.

15 Ashyralyyeva, M.A. \& Ashyralyyev, A. (2015). Stable difference scheme for the solution of the source identification problem for hyperbolic-parabolic equations. AIP Conference Proceedings, $1676,020024$.

16 Ashyralyyeva, M. \& Ashyraliyev, M. (2016). On a second order of accuracy stable difference scheme for the solution of a source identification problem for hyperbolic-parabolic equations. AIP Conference Proceedings, 1759, 020023.

17 Ashyralyyeva, M. \& Ashyraliyev, M. (2018). Numerical solutions of source identification problem for hyperbolic-parabolic equations. AIP Conference Proceedings, 1997, 020048.

18 Ashyralyyeva, M.A. \& Ashyraliyev, M. (2018). On the numerical solution of identification hyperbolic-parabolic problems with the Neumann boundary condition. Bulletin of the Karaganda University-Mathematics, 91, 3, 69-74.

19 Ashyralyev, A. \& Sarsenbi, A.M. (2015). Well-posedness of an elliptic equation with involution. Electron. J. Differential Equations, 284, 1-8.

20 Ashyralyev, A. \& Sarsenbi, A. (2017). Well-posedness of a parabolic equation with involution. Numer. Funct. Anal. Optim., 38, 10, 1295-1304.

21 Ashyralyev, A. \& Sarsenbi, A.M. (2016). Stability of a hyperbolic equation with the involution. Springer Proc. Math. Stat., 216, 204-212.

22 Ashyralyev, A., Karabaeva, B. \& Sarsenbi, A.M. (2016). Stable difference scheme for the solution of an elliptic equation with involution. AIP Conference Proceedings, 1759, 020111.

23 Ashyralyev, A. \& Sobolevskii, P.E. (2004). New Difference Schemes for Partial Differential Equations, Operator Theory Advances and Applications. Birkhauser Verlag, Basel.

24 Samarskii, A.A. \& Nikolaev, E.S. (1989). Numerical Methods for Grid Equations: Iterative Methods. Birkhauser Verlag, Basel. 